\title{
B.W. ZEIGARNIK AND PATHOPSYCHOLOGY
}

Valentina V. Nikolaeva

Lomonosov Moscow State University

Moscow

\begin{abstract}
The present work suggests an analysis of B.W. Zeigarnik's contribution into development of pathopsychology as a branch of clinical psychology. There are considered the main theoretical and methodological problems of pathopsychology which were elaborated in B.W. Zeigarnik's works. The problems of coordination between pathopsychology, general psychology and psychiatry, formulated by B.W. Zeigarnik, as well as specific features of the subject matter of pathopsychology are also discussed.
\end{abstract}

Keywords: pathopsychology, psychiatry, pathopsychological syndrome, psychological mechanisms of mental disorders.

The very name of a prominent psychologist, Bluma Zeigarnik (19001988), is world-known. Her scientific works are translated into many languages and have long since become the international fare in psychology. The first success came to B.W. Zeigarnik as early as 1920s, and was brought by her Diploma paper presented at the University of Berlin. She had conducted an investigation, under the supervision of her professor, Gestalt psychologist Kurt Lewin, which lead to a discovery of the phenomenon that people remember uncompleted or interrupted tasks better than completed ones. The discovery has been known ever since as "Zeigarnik effect" (Zeigarnik, 1927).

However, the main part of the scientific biography of B.W. Zeigarnik is closely connected with her studies conducted in Russia since 1930s. The most renowned are her works in pathopsychology (one of the branches of clinical psychology), which comes as a borderline between psychology as psychiatry. Her scientific legacy in this field has not yet been properly considered, though such study is urgent from both, scientific and practical point of view. The former reason is dictated by the increasing tendency for interdisciplinary research, since many in- 
ner problems of pedagogics, medical science and even technology are impossible to solve without consideration of a human factor (Zeigarnik, 1986, p. 4). There emerge new spheres of psychology "conterminous" to other branches of scientific knowledge (psychology of economics, mathematical psychology, or psychogenetics, to mention just a few (Zhuravlev, 2002)). In the light of this increasing tendency, establishment of pathopsychology, which foundation was profoundly contributed by B.W. Zeigranik (alongside with V.M. Bechterev, L.S. Vygotsky, and V.M. Myasishchev), may supply a scientific basis for theoretical and methodological development of these newly arising interdisciplinary spheres. It may help articulation of particular psychological problems and research in their adequate solution. Pathopsychology, itself the realm of interdisciplinary research, comes as the pioneering experience in creation of a bordering discipline, which could assimilate main postulates of the general psychology and psychiatry, while preserving the particular psychological character of study.

The practical side of the study of B.W. Zeigarnik's work may provide a useful basis for the development of psychological service in the country. Pathopsychology as a science was established in the XX century in response to insistent demands in Medical Care - and particularly, the needs of clinical practice. It might be the right place to mention the fact that the very first laboratories open on the basis of mental health clinics were founded in Russia in the XIX century: V.M. Bechterev's laboratory in Kazan, and then in St.Petersburg; S.S. Korsakov's laboratory in Moscow; I.A. Sikorsky's laboratory in Kiev, and others. In the middle of the $\mathrm{XX}$ century specialists in pathopsychology get to be employed in psychiatric hospitals facing the whole range of practical tasks: diagnostical, expert, and rehabilitative. B.W. Zeigarnik did much for organization of psychological service in psychiatry, working in close cooperation with V.N. Myasishchev and his followers. Her experience may well be adopted at the present stage of development of Russian psychology, when various problems of scientific, legislative and methodological support of psychological service centres are to be settled.

The present article is focused on the analysis of basic aspects of B.W. Zeigarnik's works on pathopsychology.

Most of B.W. Zeigarnik's works were concerned with clinical reality, which embraces psychiatric disturbances in different mental affections. The clinical reality is complicated, multiform and hard-to-reach by a 
study. To take the risk of employing an experimental method in studying a pathological case would require not only a remarkable ingenuity, scientific intrepidity, but human tact, as well as caution (one should follow the ethical imperative of Hippocratic mandate). But it was the experimental study of mental disorders, which B.W. Zeigarnik set herself to accomplish; the new province of scientific knowledge, which she was profoundly concerned to develop, she would call experimental pathopsychology (Zeigarnik, 1962, 1965, 1971, 1986). This was by no means a play of chance. Having started her scientific career under the supervision of Kurt Lewin, she would persistently maintain certain principles she had adopted from her teacher. First and foremost, she propagated the priority of theory in psychology and importance of its verification by the experiment. Another landmark for her was theoretical foundations of the scientific school represented by L.S. Vygotsky (1983a,b), A.N. Leontyev (1975), A.R. Luria (1973). Back to the USSR in the beginning of 1930s, B.W. Zeigarnik starts to work in close contact with L.S. Vygotsky and A.R. Luria, later she is drawn to A.N. Leontyev. Sharing their ideas, she becomes their teammate. The principal postulates of the concept of cultural and historical development of mental structures (i.e. formation of higher mental functions intravitam, their social and historical determination, their mediated structure and volitional character of operation) contributed to general psychological foundations of B.W. Zeigarnik's research in pathopsychology. These postulates formed a vector for the development of the focal point of her study - the subject of the newly established science. With that she would insist on the principal delimitation of the subject of psychiatry. She would repeatedly consider the question in all her works starting from 1950s and up to the end of her life. Her contention was that pathopsychology is a border-line territory between psychology and psychiatry, but it still belongs to psychology. This is how she expressed it in one of her works: "Budding off the 'parental' science, interdisciplinary and bordering spheres of knowledge, still comply with its principal laws, though they 'absorb' and assimilate many theses and facts of scientific study of the conterminous discipline" (Zeigarnik, 1986, p. 4). Pathopsychology admits "parental" relations with general psychology, but "absorbs" and assimilates the regularities of the norm in formation and operation of mental processes for its scientific research of mental disorders. As B.W. Zeigarnik would argue, the analysis of pathological phenomena "within the framework of general 
psychology" (Ibid.) is essential, because "otherwise the very subject of study will be dissipated" or replaced "by the subject of a science, to which the psychological knowledge is applied" (for example, the so called small psychiatry, pathophysiology, and the like) (Ibid., p. 4). This kind of substitution is not always evident, and quite frequently "may even impress as a way to search for objective (physiological) mechanisms" (Zeigarnik, 1970, p. 6). But in sober fact such substitution may well lead to the loss of the specific character of psychological science. The very fact that brain activity is indispensable for psychic processes does not make these processes less psychic (Ibid.). Pathopsychology, being a branch of psychology, takes as a premise the regularities of development and functioning of psychic in its norm, and endeavors the study of mechanisms of break-up (decay) of mental activity and individuality as opposed to the norm. It is the backbone of psychological knowledge, which determines, according to B.W. Zeigarnik, conceptual apparatus of pathopsychology, the very logic of analysis of mental disorders, as well as methodological approach to their study.

Such conception of the subject of a bordering sphere of knowledge may suggest a number of important scientific and practical effects. As for the scientific side of it, this approach provides a certain angle for the analysis, that is, it helps discriminate, theoretically and empirically, a single psychological link, represented both, in the norm and break-up or decay. It helps understand in what way certain specific terms of disease may distort general regularities of mental life and change its structure.

From the practical point of view, this approach directs the specialists in psychology to preserve a specific character of their professional activity and autonomy (while encouraging interdisciplinary contacts). This seems to be the only way to provide effective and competent accomplishment of professional tasks: expertise, diagnostics or psychological assistance. This is the only case when a specialist may be able to flesh out the clinical reality with psychological content, providing a new angle, which lies beyond the reach of his colleague-clinician.

Involved in the discussion of the subject-matter of pathopsychology, B.W. Zeigarnik maintained, that it's content will be gradually enriched, among other things, by the broadening range of pathological phenomena, amenable to pathopsychological analysis. Among these she would mention mental changes and disorders in patients with chronic somatic diseases, as well as the number of boundary cases in patients who suf- 
fered severe psychological stress or had a long period of adjustment to life difficulties, the uncertainty or psychological distress. This broadening of the range of pathopsychological phenomena, it was B.W. Zeigarnik's deep conviction, should result in the discovery of new psychological mechanisms, not only responsible for abnormal functioning of the psyche, but enabling people to cope with life's challenges and to triumph over them.

This prognostication was proved to be true by the development of Russian psychology in the last decades of the XX and the beginning of the XXI century. One of the primary methodological concepts, which B.W. Zeigarnik abidingly maintained, is the recognition of the paramount importance of theory for the development of borderline branches of psychology (pathopsychology, in particular). In this connection she would naturally repeat in her oral reports and publications the idea of an Austrian physicist Ludwig Boltzmann, that a good theory is the most economizing thing in a science (Zeigarnik \& Bratus, 1980; Zeigarnik, 1986). In any discussion she stood as a fervent advocate of the importance of theoretical knowledge, criticizing unsound empiricism in science as well as reductionism of different manifestations (Zeigarnik \& Bratus, 1980; Zeigarnik, 1982).

Since B.W. Zeigarnik was a consistent follower of Vygotsky-LuriaLeontiev school in psychology, she would assign a fundamental importance to the concept of development and formation of higher mental functions intravitam. Understanding of the laws of normal development she regarded as a key to the study of pathological phenomena of the psyche. In accordance with her approach, the principal psychological laws of development and functioning of the psyche in terms of disease are very much the same that those of the norm. But they are realized in a distorted form, as a result of: a) the change in biological conditions of the psyche, caused by brain pathology in mental illness; b) special; "narrow" framework of patient's life, limited by the disease (Bratus, 1988; Zeigarnik \& Bratus, 1980).

Moreover, she believed, it is the unity of basic psychological laws, which leads us to the conclusion that our study of mental disorders gives us the clue to the psyche of a sound man. In this B.W. Zeigarnik shared the opinion of some of her forerunners, that pathology could uncover before the eyes of a scientist many new things about psychic life of man, the things, which are hidden if we regard a sound man (Gannushkin, 
1964; Luria, 1973). Thus, in her description of mental disorders she usually takes a "reverse step" - from pathology to the norm - to see what exactly can be explained in psychological life of a sound man through the analysis of this or that pathological phenomenon. So it was quite natural that all editions of her text-book "Pathopsychology" included a chapter "On the Importance of Pathopsychological Study for the Theory of General Psychology" (Zeigarnik, 1986).

This "feed-back" with theoretical concepts of general psychology is essential, as B.W. Zeigarnik believed, not only for scientific research in pathopsychology, but for practitioners working in residential psychiatric facilities. The knowledge in general psychology will broaden professional skills of the specialist; improve his competence in practical tasks, providing a scientific foundation for his expertise and diagnostic findings. Without the theoretical basis, B.W. Zeigarnik would insist, a practitioner would become a journeyman in his work, and a specialist of any other field may serve a good substitution for him. This new specialist might be well-versed in problems of, say, clinical medicine, but would never be able to express the specific character of the subject-matter of pathopsychology. While, professional growth of a psychologist is only possible, when he acts within the framework of his own subject.

Scientific traditions of Vygotsky-Luria-Leontyev school suggest a certain logic for the analysis of pathological phenomena, presenting a succession of "steps", each of which should bring the scientist closer to the discovery of the nature of a certain pathological phenomenon. The following succession shows the main "steps": 1) to mark the psychological, i.e. culturally determined, phenomena of mental disorders in the clinical picture of the disease; 2 ) to investigate into psychological mechanisms of their emergence; 3 ) to discover the basic regularities of functioning.

Let us take each of the steps in more details. Pathological mental phenomena, observed in clinics, are described in the system of mental concepts. B.W. Zeigarnik believes that classification of clinical phenomena in the system of psychological concepts is the first (and very important) step in the analysis of mental disorders; phenomena, which were not articulated in the categories of psychological theory, cannot say a new word in our comprehension of the pathology. In this case we can do nothing, but "return" the clinic the already established facts. The psychiatrist, following the results of his own descriptive method, suggested 
in clinic, may impress with the more accurate and convincing characteristics of a pathological phenomenon. But he is confined within the strict limits of his clinic psychiatric approach. Only when psychological qualification of the facts within the concepts of contemporary psychology is accomplished, there arrives an opportunity to bring them to the logic of psychological analysis, which may result in a discovery of new qualities in analyzed phenomena.

Real implementation of this methodological principle into practice can be found in a number of B.W. Zeigarnik's works concerning the pathology of though (Zeigarnik, 1958, 1962). Aphronia of different kinds belongs to the most common type of mental disorders. It may come with different mental diseases, its clinical manifestations are multiform and difficult to systematize. At the same time, understanding of these disorders (their nature, dynamics, etc.) is of primary importance for both diagnostics, and for the choice of strategy of psychological treatment, for understanding of the defect's structure, general prognosis, etc. Clinical psychiatry may suggest only numerous descriptions of the phenomenon, but it has no classification of aphronia cases so far. To describe a certain mental disorder psychiatry often employs metaphors or everyday notions. For example, the way of thinking for patients with schizophrenia in clinical description suggests weirdness and abnormality of judgments: such patients are characterized by the "blocking of thought", incoherence of thought, etc. (Snezhnevskij, 1983).

Development of the original and consistent classification of aphronia cases belongs to uncontestable merits of B.W. Zeigarnik. Following S.L. Rubinshtein, A.N. Leontyev and others she considers thinking as cognitive activity, which "rests upon the system of concepts, aims to the solution of a task, subjected to a certain purpose, and is taking into consideration the terms, under which the task is being accomplished" (Zeigarnik, 1986, p. 177). She also suggests that general structure of the act of thought is similar for pathology and the norm.

However, in mental disorders certain links in thinking might be either reduced, or excessively developed, fleshed-out, or distorted. This very effect creates the "weird" picture, introduced in text-books on psychiatry. At this point the scientist has to discover, which links of the thinking process are affected and in what way they are affected; what are the psychological mechanisms of these disorders. The whole clinical phenomenology of aphronia was psychologically qualified in works of B.W. 
Zeigarnik, it was systematized in accordance with a single criterion - the place of a phenomenon in the structure of intellectual activity.

A single criterion made it possible to distinguish three types of disorders in thinking: operational (distortion of intellectual operations or reduction of the level of their realization), dynamic (lability of thinking or mental inertia) and motivational (violation of critical thinking, diversity of opinions, and philosophizing) (Zeigarnik, 1958, 1962, 1986; Telenitsina, 1965). Such an approach presents aphronia not as separate cases, but as a psychologically complicated system, in which structure one can distinguish central, leading (i.e. primary) disturbances, as well as dependant (i.e. secondary) phenomena. The content and genesis of primary and secondary disturbances in aphronia, as B.W. Zeigarnik shows in her works, are different in mental diseases of different types, that is, they are of nozo typical character. She particularly shows in her works that in cases of schizophrenia the leading role in the structure of aphronia is performed by disturbances on motivational-personal level: they underlie the break-up in operation of thinking. This conclusion made by B.W. Zeigranik was verified many times; it acquired experimental justification and adjustment in the series of works conducted by Yu.F. Polyakov, his colleagues and disciples (Kritskaya, Meleshko, \& Polyakov, 1991). Quite a different psychological picture reveals itself in such diseases as epilepsy or idiophrenia of various genesis. The central link in the structure of disturbances in these cases of aphronia is the change in dynamics of mental activity (its lability or inertia), which often comes in combination with the reduction in the level of performance of mental operations.

The results, achieved by B.W. Zeigarnik in her study of aphronia cases, suggested a new series of works, concerned with the research of other types of cognitive activity, i.e. perception and memory (Petrenko, 1976; Safuanov, 1998). It was found that principles worked out for the model of aphronia might be as well effective in the study of such types of pathology in cognitive sphere; they allow to describe phenomenology of similar disturbances in the system of psychological concepts, allowing to mark separate links in the hierarchical structure of disturbances, to understand their psychological nature. In particular, it was demonstrated that a break-up in memory and perception in mental diseases, as well as aphronia, may be caused by the pathology in motivational-personal link of intellectual activity. Thus patients with traumatic lesion of the frontal lobes revealed intact the processes of retention, preservation and repro- 
duction of the material, but would often "forget their intentions, went wrong with their obligations and solutions" (Zeigarnik, 1965, p. 10). This was caused by the change in attitude to what was happening, the state of detachment; that is the motivation link was affected.

The study of pathology in cognitive activity drove B.W. Zeigarnik to the conclusion of the essential importance of the study of patient's personality for the assessment of his psychological state and general understanding of the defect's structure. These are her own words: "Any problem suggested by psychiatric practice, whether it concerns the examination of disability, or the study of the structure of remission, or the effectiveness of treatment - the data of psychological study comes useful only then and there, when and where they suggest a qualification of the whole personality rather than a certain mental process" (Zeigarnik, 1970, p. 12). Another series of her papers was concerned with the study of personality disorders in patients with various mental diseases (Bratus, 1974; Zeigarnik, 1971; Leontiev, 1975; Kareva, 1975; Kornilova, 1980).

B.W. Zeigarnik came in tune with A.N.Leontyev in that the personality basis is structured by a hierarchical system of motives (Mazur, 1983). Realizing entirely that personality as a whole cannot be boiled down to just a hierarchy of motives, she regards them as a key formation, shaping the general picture of behaviour, man's relation to the world, other people and his own self. In works of her disciples (Bratus, 1974; Leontiev, 1975; Kareva, 1975; Kornilova, 1980) there were studied disturbances of the motivational sphere in patients with various diseases. There were indicated principal 'psychological' phenomena, and their connection with the clinical picture of the disease was described. It was demonstrated, that psychic pathology might be psychologically expressed through a) the formation of pathological needs and motives (Bratus, 1974, 1988; Kareva, 1975); b) by the change of the structure and hierarchy of motives (Ibid.); c) in break-up of: meaning making (Leontiev, 1975); goal-setting and goal achievement (Kornilova, 1980); d) personal criticism; e) self-regulation (Zeigarnik, Holmogorova, \& Mazur, 1989; Leontiev, 1975; Holmogorova, 1983). This line of research was continued by her disciples, who succeeded in description of complex psychological phenomena of impairment of self-consciousness in borderline personality disorders (Sokolova, 1989) as well as a wide range of pathopsychological phenomena in practice of forensic psychological examination (Safuanov, 1998). 
In the series of her works on pathopsychology, B.W. Zeigranik dwells on the problem of psychological mechanisms as such, provoking various pathological phenomena. As she presented it, alongside with physiological - cerebral - mechanisms of mental disturbances, there can be distinguished a special - psychological - type of such mechanisms. Following L.S. Vygotsky, she suggested that brain damage cannot unambiguously qualify the symptom of the disease. One should by no means ignore the processes of development and compensation of the defect in a patient. "It is methodologically typical and justified to seek for the explanation of numerous psychopathological symptoms, taking into consideration psychological laws. It would be a mistake to assert that only physiological or anatomical structure could provide an exhaustive explanation, though we admit its importance" (Zeigarnik, 1970, p. 6). It was obvious for B.W. Zeigarnik that certain demands of life, or terms of the disease might lead to secondary mental disturbances in a patient, that is, as her close adherent S. Ya. Rubinshtein asserted, "a qualifying cause of each symptom may be quite different, it is not preset or predetermined by the very brain damage" (Rubinshtein, 1965, p. 18).

This methodological approach enabled B.W. Zeigarnik to appoint the activity of the patient himself as a subject of life for the most important factor of symptom formation in mental diseases. It is the distortion of personal activity of the patient in terms of the disease, which may produce pathological mental phenomena. B.W. Zeigarnik's followers studied a few disturbances of this kind. In the work of S.Ya. Rubinshtein (Rubinshtein, 1976), for example, one of the cases of auditory hallucinations was investigated. It was demonstrated that under the conditions of sensory deprivation, when an active drive for harking is set, a fraud hearing of different kind might be provoked. This, as it was exposed by her works, was possible only when the patient had already possessed a "hallucinatory experience". The contents, intensity and emotional strength of a fraud hearing may be connected with the character of the experiment, or personal experience of the patient, as well as peculiarities of the disease. Another example: B.W. Zeigranik describes the phenomenon of wrong solution of intellectual tasks with patients suffering organic brain damage, when the structure of mental activity is generally preserved, and the patient is over-motivated for the success and praise. Under these conditions the direction of expertise of a psycho-diagnostical study may acquire excessive intensity and keenness, which may cause increased 
self-control in the patient. This, in its turn, may result in faults and errors in intellectual tasks solution (that is, the emergence of a psychologically caused symptom) (Zeigarnik, 1958, 1962, 1965).

Pathopsychologists come across another phenomenon of similar genesis, this is the phenomenon of random slowing down of activity under the conditions of expert evaluation (for example, labour expertise), when patients demonstrate a strongly expressed set for a high quality performance, or, on the contrary, when they strive to accentuate their inconsistence in accomplishing diagnostical tests. We could go on with examples. It is essential that in each of these cases it is the activity of the patient, his personality, his attitudes and direction, which may cause rather simple (a slowdown), as well as pathological phenomena (hallucinations).

B.W. Zeigarnik would attach special attention to a study of the role and place of the patient's activity in symptom formation, regarding this problem as one of the most perspective in pathopsychology. Investigation on this direction, she believed, would make it possible in future to approach the deeper understanding of the complex psychopathological phenomena, "suggesting new opportunities in the analysis of quality structure of psychopathological symptoms and syndromes" (Zeigarnik, 1965, p. 13).

As a consistent follower of Vygotsky's school in psychology, B.W. Zeigarnik in many of her works paid special attention to the analysis of symbolic mediation, regarding it as one of the most important psycho logical mechanisms of symptom formation. Peculiarities of mediation may sometimes "turn from the factor, regulating activity, into the factor, contributing to the formation of a painful syndrome" (Zeigarnik, 1970, p. 1). In the norm, mediation "does not overshadow the very content of the activity, does not destroy it" (Ibid.). In the pathology the process can be distorted by the use of a means inadequate to the conditions of the task (it happens in schizophrenia), there may as well be the phenomenon of exaggerated mediation (in epilepsy), mediation may as well be inaccessible process (in pathology of the frontal brain of different genesis). In each of these cases highest psychic functions are damaged: arbitrary memory, arbitrary attention, thinking; patient's behaviour as a whole is affected, the ability for self-regulation is lost or distorted - the process, which Vygotsky called "mastering of one's behaviour" (Vygotsky, 1983a,b). In this way, Vygotsky's concept that human psyche, both in 
norm and pathology, has a complex, systematic structure is empirically supported in works of B.W. Zeigarnik, her disciples and followers.

For B.W. Zeigarnik, as for every adherent of Vygotsky-Luria-Leontyev, the most essential question is that of fundamental principles of analysis of mental disorders. One of the prominent achievements of this school, as it is widely recognized, is theoretical and empirical foundation of syndrome analysis - the means, which enables the description of the structure of disturbances, psychological interpretation of clinical phenomenology, distinguishing of the psychological mechanisms of abnormal phenomena in psyche. In her formulation of the principles of pathopsychological experiment (Zeigarnik, 1965, 1970, 1986) B.W. Zeigarnik closely approached the idea of the necessity and possibility to distinguish a special - pathopsychological - syndrome, which is not identical to the clinical one. Though we can hardly find the term "pathopsychological syndrome" in her works, but the subject was being widely discussed by B.W. Zeigarnik with colleagues and disciples in late years of her life. Some works of her disciples, published during her lifetime, suggest not only the definition of the syndrome, but the discussion of practical problems, connected with application of pathopsychological syndromic analysis.

Pathopsychological syndrome is regarded in the context of B.W. Zeigarnik's works as a hierarchically organized system, "a relatively stable, internally connected complex of separate symptoms - disturbances, which shows itself in emotional reaction and cognitive activity of the patient" (Praktikum po patopsikhologii, 1987, p. 36). (This definition belongs to E.T. Sokolova). Syndromic analysis does not appear to be a merely empirical instrument, it rests upon the principles of psychological study, formulated in Vygotsky's school; it assumes a qualitative analysis of the results and their psychological interpretation aimed at the description of the systemic structure of a certain defect (Vygotsky, $1983 \mathrm{a}, \mathrm{b})$. The very first, impressive samples of pathopsychological analysis can be found in works of L.S. Vygotsky (we can take as an example his work concerned with the structural analysis of the defect in Pick's disease (Samuhin, Birenbaum, \& Vygotsky, 1934)).

Pathopsychological syndromic analysis allows to distinguish mental disturbances in the defect's structure which are different in genesis, in time of emergence, and in function. Combination of these factors creates the complicated mosaic of patient's mental life, in which the phenomena 
of disruption closely intertwine with development, compensation, etc. (Ob jeksperimental'no-psikhologicheskom issledovanii bol'nyh..., 1956). Picking up the problem of correlation of disruption and development in psyche, B.W. Zeigarnik actually relies on the results of syndromic analysis. She verifies, theoretically and empirically, the concept of nonidentity of mental defect in patients to the state of mental activity of a child on different stages of ontogenesis. The idea that mental disruption does not come as negative in its development is a keynote of all works of Bluma Zeigarnik.

Pathopsychological syndromic analysis allows to take a fresh look at the nature of clinical phenomenology; at this point it becomes obvious, that clinical and pathopsychological syndromes are not identical in their contents. The works of B.W. Zeigarniks and her disciples demonstrate that clinical phenomena, remote from each other, may be close in genesis and psychological mechanisms. For example, pathological apastia in anorexia nervosa (Kareva, 1975) and pathological need for alcohol (Bratus, 1974, 1988) share the same psychological mechanism, provoking establishment of a clinical syndrome. At the same time, similar clinical phenomena may come as psychologically different. Several structurally different pathopsychological syndromes may correspond to one clinical disturbance (this was vividly shown in works of Yu. F. Polyakov, T.K. Meleshko, V.L. Kritskaya, who studied pathologies of mental activity in schizophrenia (Kritskaya, Meleshko, \& Polyakov, 1991).

The study of pathopsychological synromology is an important problem of current interest in present-day pathopsychology. Further development of the problem seems to be essential. For the present a few plausible directions of investigation may be pointed out. One of them concerns development of typology of pathopsychological syndromes of disturbances of separate mental processes (memory, thinking, etc.); various basic syndrome forming factors should be distinguished. Another plausible sphere lies in development of pathopsychological nozo typical syndromology; a third branch may set to develop the foundations of pathopsychological syndromic analysis for complicated psychopathic phenomena, such as delirium, hallucinations, clinical syndrome of psychic automatism, etc. The latter was marked by B.W. Zeigarnik as the most perspective branch of study, which may open "fresh opportunities for the analysis of qualitative structure of psychopathic symptoms and syndromes" (Zeigarnik, 1965, p. 13). 
A remarkable contribution of B.W. Zeigarnik to the development of pathopsychology comes with introduction of a special type of diagnostic procedure, which she called a "pathopsychological experiment". It brings many experimental findings of Levin's school into synthesis with a classical experiment in psychology. A distinguishing feature of this technique is the inclusion of experimentalist - his personality, attitude to his patient, his judgments - as a vital factor for influence on the patient with the purpose of stimulation of his activity, intensification of his emotional response and critical perception of the situation. Such type of experiment, as B.W. Zeigarnik believed, allows modulation of "real emotions, true reactions, objective behaviour", "to reconstruct the real layer of life with all its nuances" (Zeigarnik, 2002, p. 377). The situation of such an experiment allows to establish the desirable type of interplay with the patient, detecting personal characteristics pf the participant, his attitudes and values. Pathopsychological experiment can be adequate only if it forms or reproduces a real life situation. It should actualize not only intellectual operation of the patient and his personal attitude, but potential ability, aptitude for learning, i.e. what Vygotsky called "zone of proximal development". In Zeigarnik's school there were developed a number of specific diagnostical procedures, aimed at valuation of the "zone of proximal development", which is particularly important for the prognosis of development, adaptation and rehabilitation of the patient.

\section{References}

Bratus, B. (1974). Psikhologicheskij analiz izmeneniya lichnosti pri alkogolizme [Psychological analysis of personality change in alcoholism]. Moscow: Izd-vo Mosk. un-ta.

Bratus, B. (1988). Anomalii lichnosti [Abnormalities of personality]. Moscow: Mysl'.

Gannushkin, P. (1964). Izbrannye trudy [The selected works]. Moscow: Medicina.

Holmogorova, A. (1983). Narusheniya refleksivnoj regulyacii poznavatel'noj deyatel'nosti $u$ bol'nyh shizofreniej [Violations of the reflective regulation of cognitive activity in schizophrenic patients]: Avtoref. dis. ... kand. psikhol. nauk. Moscow.

Ivanova, A. (1976). Obuchaushij eksperiment kak metod ocenki umstvennogo razvitiya detej (metodicheskie rekomendacii) [Teaching experiment as a method of assessing cognitive development (guidelines)]. Moscow. 
Kareva, M. (1975). Ob odnom vide formirovaniya patologicheskogo motiva $v$ podrostkovom vozraste [A form of the formation of pathological motive in adolescence]: Avtoref. dis. ... kand. psikhol. nauk. Moscow.

Kornilova, A. (1980) Narusheniya celepolaganiya u psikhicheski bol'nyh [Violations of goal-setting of the mentally ill]: Avtoref. dis. ... kand. psikhol. nauk. Moscow.

Kritskaya V., Meleshko T., \& Polyakov Yu. (1991). Patologiya psikhicheskoj deyatel'nosti pri shizofrenii: motivaciya, obschenie, poznanie [The pathology of mental activity in schizophrenia: motivation, communication, cognition]. Moscow: Izd-vo Mosk. un-ta.

Lavrinovitsh, A., \& Moskalenko, E. (1984). K probleme kvalifikacii rezul'tatov patopsikhologicheskogo issledovaniya [The problem of qualification of the results of pathopsychological research]. Zhurnal nevropatologii i psikhiatrii, 12.

Lazursky, A. (1900). Vliyanie estestvoznaniya na razvitie psikhologii [The influence of natural sciences on the development of psychology]. Obozrenie psikhiatrii, nevrologii i jeksperimental'noj psikhologii, 8, 594-597; 9, 660-670.

Leontiev, A.N. (1975). Deyatel'nost', soznanie, lichnost' [Activity, mind, personality]. Moscow: Politizdat.

Luria, A. (1973). Osnovy nejropsikhologii [Fundamentals of neuropsychology]. Moscow: Izd-vo Mosk. un-ta.

Mazur, E. (1983). Smyslovaya regulyaciya deyatel'nosti [Semantic regulation of activity]: Avtoref. dis. ... kand. psikhol. nauk. Moscow.

Nikolaeva, V., Sokolova, E., \& Spivakovskaya, A. (1979). Specpraktikum po patopsikhologii [Pathopsychology, Practical work]. Moscow: Izd-vo Mosk. un-ta.

O rabote patopsikhologa $v$ psikhiatricheskoj bol'nice [The work of pathopsychologist in psychiatric clinic]. Metodicheskoe pis'mo (1975). Moscow.

$\mathrm{Ob}$ jeksperimental'no-psikhologicheskom issledovanii bol'nyh $v$ psikhonevrologicheskih uchrezhdeniyah [On an experimental psychological study of patients in neuropsychiatric settings]. Metodicheskoe pis'mo (1956). Moscow.

Petrenko, L. (1976). Narusheniya vysshih form pamyati [Violations of the highest forms of memory]. Moscow: Izd-vo Mosk. un-ta.

Praktikum po patopsikhologii [Practical work. Pathopsychology] (1987). Moscow: Izd-vo Mosk. un-ta.

Rubinshtein, S.Ya. (1965). Ispol'zovanie jeksperimental'nogo metoda dlya izucheniya psikhopatologicheskih yavlenij [Using an experimental method to study psychopathological phenomena]. In Voprosy e'ksperimental'noj patopsikhologii [Issues of experimentak psthopsychology]. Moscow.

Rubinshtein, S.Ya. (1976). Patologiya sluhovogo vospriyatiya [Pathology of the auditory perception]. Moscow: Izd-vo Mosk. un-ta. 
Safuanov, F. (1998). Sudebno-psikhologicheskaya e'kspertiza $v$ ugolovnom processe [Forensic psychiatric examination in criminal proceedings]. Moscow: Gardarika, Smysl.

Samuhin I., Birenbaum G., \& Vygotsky L. (1934). K voprosu o demencii pri bolezni Pika [On the question of dementia in contest of Pick disease]. Sovetskaya nevropatologiya, psikhiatriya i psikhogigiena, 3(6).

Snezhnevskij, A. (Ed.). (1983). Rukovodstvo po psikhiatrii [Guide to psychiatry]. Moscow: Medicina.

Sokolova, E. (1976). Motivaciya i vospriyatie v norme i patologii [Motivation and perception in health and disease]. Moscow: Izd-vo Mosk. un-ta.

Sokolova, E. (1989). Samosoznanie i samoocenka v norme i patologii [Self-awareness and self-esteem in health and disease]. Moscow: Izd-vo Mosk. un-ta.

Telenitsina, T. (1965). O psikhologicheskoj strukture rezonerstva [On the psychological structure of reasoning]. In Voprosy e'ksperimental'noj patopsikhologii. Moscow.

Vygotsky, L. (1983a). Defekt i kompensaciya [Defect and compensation]. In L.Vygotsky, Collected works. Vol. 5. Moscow: Prosveschenie.

Vygotsky, L. (1983b). Diagnostika razvitiya i pedologicheskaya klinika trudnogo detstva [Diagnostics of development and pedological clinic of difficult childhood]. In L.Vygotsky, Collected works. Vol. 5. Moscow: Prosveschenie.

Zeigarnik, B. (1927). Uber das Behalten erledigter und un-erledigter Handlundeh. Psyshologisshe Forsshung, 9.

Zeigarnik, B. (1958). Narusheniya myshleniya u psikhicheski bol'nyh [Disturbances of thinking in psychiatric patients]. Moscow: Gos. NII psikhiatrii.

Zeigarnik, B. (1962). Patologiya myshleniya [Pathology of thinking]. Moscow: Izdvo Mosk. un-ta.

Zeigarnik, B. (1965). Predmet i zadachi patopsikhologii [Subject and tasks pathopsychology]. In Voprosy eksperimental'noj patopsikhologii [Problems of experimental pathopsychology]. Moscow.

Zeigarnik, B. (1970). Znachenie psikhologicheskoj teorii dlya patopsikhologii [The value of psychological theory for pathopsychology]. In Voprosy patopsikhologii [Issues of pathopsychology]. Moscow.

Zeigarnik, B. (1971). Lichnost' i patologiya deyatel'nosti [Personality and pathology of activity]. Moscow: Izd-vo Mosk. un-ta.

Zeigarnik, B. (1982). Teorii lichnosti v zarubezhnoj psikhologii [Theories of personality in foreign psychology]. Moscow: Izd-vo Mosk. un-ta.

Zeigarnik, B. (1986). Patopsikhologiya [Pathopsychology]. Moscow: Izd-vo Mosk. un-ta.

Zeigarnik, B. (1990). K. Levin i sovetskaya psikhologiya [K. Levin and soviet psychology]. Vestnik Mosk. un-ta. Seriya 14, Psikhologiya, 4. 
Zeigarnik, B. (2002). Ob eksperimente v shkole K. Levina [About an experiment in school of K. Levin]. In Jeksperimental'naya psikhologiya. Praktikum [Experimental psychology. Practice]. Moscow: Aspekt Press.

Zeigarnik, B., \& Bratus, B. (1980). Ocherki po psikhologii anomal'nogo razvitiya lichnosti [Essays on the psychology of abnormal personality development]. Moscow: Izd-vo Mosk. un-ta.

Zeigarnik, B., Holmogorova, A.B., \& Mazur, E.S. (1989). Samoregulyaciya povedeniya v norme i patologii [Self-regulation of behavior in health and disease]. Psikhologicheskij zhurnal, 10(2).

Zhuravlev, A. (2002). Specifika mezhdisciplinarnyh issledovanij v psikhologii [Specificity of interdisciplinary studies in psychology]. Psikhologicheskij zhurnal, 23(6). 